\title{
Dawn of a New Hope at Makutupora Leprosy Settlement.
}

R. BANKs.

N 1929, the Church Missionary Society accepted responsibility for the little settlement for sufferers from leprosy, known officially as Makutupora, which is in the Manyoni district of the Dodoma Province in Tanganyika Territory. For some time things had been in an unsatisfactory condition, and it was with much joy that the patients received the news that there was hope of a better day. There were just over a hundred cases in the camp, the women outnumbering the men by two or three; there is also a fair sprinkling of children. With the prospects of a doctor being located to the mission station at Kilimatinde, only nine miles away, it was not only hoped to make life brighter for the incurables, but to give treatment to all early cases and children. A good start was made, however, before the doctor's arrival, and much patient sorting-out and preliminary work was done by Sister Hobbs who regularly visited the settlement attending to general ailments and giving injections. By har cheerful methods of approach she wore down distrust and suspicion and gained the confidence of all patients.

The settlement nestles in the foothills on the southeastern slopes of the Saranda-Kilimatinde escarpment which overlooks the western portion of the thickly-populated Unyangwila plain. The situation as a segregation camp is excellent, although a rocky projection running out on the lower side of the valley shuts off some of the prevailing winds. Water is good and abundant in quantity. We found it quite open and unprotected from the wild animals which prowl around, and scores of baboons with other beasts as well as native cattle drank promiscuously at the same pools from which those afflicted with leprosy drew their daily supplies; occasionally the women would be obliged to wait their turn until whole families of baboons had taken their fill. The soil is fertile though stony, and in a normal season splendid crops of millet and maize can be raised, though much of the harvest is destroyed through the ravages of baboons. The settlement is well off the beaten track and separated by a thick belt of bush from the nearest villages two miles distant, yet it is easily accessible from Kilimatinde along an all-weather motor road which we have made.

With the aid of a generous building grant from the 
British Empire Leprosy Relief. Association, a three-roomed erection was put up to serve as treatment room and drug store, food store, and rest house, whilst at Kilimatinde a base store was built to house the reserves of corn and rice which are bought on the market, and from here supplies are taken down to the settlement as required, usually once a week on a Ford box body car ; formerly all food had to be transported on the heads of caravan porters, and much work was involved making up and distributing loads sufficiently small for them.

The system of the distribution of the food which had always been a source of much dissatisfaction was overhauled and new methods were adopted which were calculated to give to every patient a sufficiency of wholesome food at regular intervals, and when the inmates realised this, a great improvement began to appear in the general tone of the place. All grievances, real or fancied, were thoroughly investigated, but to save time in listening to numbers of trifling complaints, a Committee of three was appointed, chosen by the patients, who would first listen to all "shauris" (matters) and what was beyond their power to remedy they referred to the superintending missionary on his visits. Besides the small though regular allowance of corn, which all were allowed to draw, patients continued to cultivate their own plantations, and were at liberty to sell it if they wished to do so. We bought a large quantity from them in this way at the prevailing market price and put it into the general store. This encouraged them to work hard on their plantations. Those known to possess big reserves in their houses were exhorted to refrain from drawing from the common store whilst their own corn lasted, although we never actually refused anybody his ration if he wanted it. We tried to inculcate a public spirit-not easy with Africans. Disabled patients as well as children were supplied with rice in addition to a modicum of corn to save the trouble of grinding-no light task for a woman minus a few fingers or without hands. During our building operations, many of the able-bodied men and youths worked on brick-making, stone collecting and other tasks and received the same pay as labourers who had been engaged from outside.

Whilst several tribes are represented our people are chiefly Wagogo and like to live in the usual Cigogo fashion, dwelling in low, flat-roofed mud houses built in rectangular shape and into the enclosed square they bring their herds and flocks at night. We intend to improve on these mud houses for, whilst being good enough for the average healthy 
native, they are constantly in need of repair beyond the strength of a disabled patient, and it is hoped to erect houses of a more permanent character which, besides being on approved lines from the hygienic point of view, will prove to be more economical in the long run than the tumble-down tembes which are dreadfully leaky and utterly miserable hovels in wet weather. Two ladies of the Mission, one a nurse and the other a deaconess, have recently offered to take up their abode at the settlement and devote all their time to the work. If this offer can be accepted, I foresee the settlement becoming very popular, and the many sufferers who, I am convinced, are hiding away in obscure villages, will emerge and seek the help and treatment we so much want them to receive.

The following extract from the report of the Medical Officer, Dodoma, forwarded by the Director of Medical and Sanitary Services, will give some indication of the progress that was made in the first half-year of the new régime.

"Since taking over the Settlement, the C.M.S. has effected a very remarkable improvement. The inmates, without exception, appeared well-fed and well-cared for, while dressings had been regularly and carefully carried out in all cases in which they were called for.

"Mr. Banks and Miss Hobbs visit the Settlement every week. At these visits, a general inspection is carried out, and Miss Hobbs administers injections of moogrol to twenty of the inmates. Along with Dr. Buntine I had the opportunity of seeing all the inmates, and think that this is a very liberal treatment list and that no useful purpose would be served by extending it.

"An excellent and substantial three-roomed building is. in course of erection on a central site overlooking the entire settlement, and is almost completed. It is intended to serve as dispensary, store-room and treatment-room. It has been suitably rat-proofed, and should meet these requirements admirably. Some of the old dilapidated buildings have been removed, and the living quarters of the inmates have been repaired. Further improvements are projected, and the spring which affords the water supply is to be protected.

"It was also gratifying to observe the heightened morale of the inmates. Some of the able-bodied males were taking part in the making of bricks and other work, and tilling of the land had been resumed. ... 